\title{
Assessment and Mitigation of Nutrients Losses from Forest Harvesting on Upland Blanket Peat - A Case Study in the Burrishoole Catchment
}

\author{
Liwen Xiao*, Michael Rodgers, Mark O'Connor \\ Connie O'Driscoll and Zaki-ul-Zaman Asam \\ Civil Engineering, National University of Ireland, Galway \\ Republic of Ireland
}

\section{Introductions}

Since the 1950s, large areas of upland peat were afforested in northern European countries. In Ireland, it was estimated that in 1990 about 200,000 ha of forest were on peatland (Farrell, 1990) and between 1990 and 2000, about 98,000 ha of peat soils were afforested (EEA, 2004). Before the 1980s, most of the Irish peatland forests were planted without riparian buffer strips in upland areas that contain the headwaters of rivers, many of them salmonid. These forests are now reaching harvestable age. Due to the sensitive of the upland water and blanket peat to the disturbance, concerns have been raised about the possible impacts of harvesting these forests and associated activities on the receiving aquatic systems (Coillte Teo, 2007). In order to minimize the possible negative impact of forest harvesting on water quality, good management practices were introduced in the UK (Forestry Commission, 1988) and in Ireland (Forest Service, 2000b, 2000c and 2000d). These practices targeted the process of soil erosion, and included proper harvesting methods and the use of thick brash mats to limit surface disturbance. The findings of earlier harvesting studies in the UK and Ireland were not relevant for the impact assessment of forestry operations carried out under the new forest and water guidelines (Stott et al., 2001). To date, few studies have focused on the impact of post-guideline harvesting on water quality (Nisbet, 2001; Stott et al., 2001). In this study, an assessment of the impact of post-guideline harvesting on the suspended solid and phosphorus release was carried out in an upland blanket peat catchment that had been afforested in the 1970s without buffer strips - typical of most Irish forests now approaching harvestable age. It comprised a control area upstream of an experimental area. We hypothesize that if the best management practice are strictly followed (1) suspended solids release will be low but (2) P release will increase significantly due to a combination of poor $P$ adsorption capacity in blanket peat soil, high rainfall $(>2000 \mathrm{~mm})$ and runoff in the study area, and labile P sources being available after harvesting.

Nutrients release to the water body can be minimized by (1) preventing the nutrients transportation from sources to water and (2) reducing nutrient sources. In Ireland and the

${ }^{*}$ Corresponding Author 
UK, many of the earlier afforested upland blanket peat catchments were established without any riparian buffer areas, with trees planted to the stream edge (Ryder et al., 2010). To reduce $P$ release to recipient water courses, buffer strips with a width of $15-20 \mathrm{~m}$ are recommended. However, their effect may be limited if (1) most of the P release occurs in storm events, when there would be low residence times for the vegetative uptake of soluble $\mathrm{P}$ and (2) most of the $\mathrm{P}$ release are dissolved reactive phosphorus. Thus, a specific aim of the study was to investigate the P release pattern in storm events, and to quantify the P release occurring during storm events and base flow conditions. In order to reduce nutrient sources, whole-tree harvesting (WTH) is recommended (Nisbet et al. 1997). In the UK, WTH is usually achieved by removing the whole tree (i.e. all parts of the tree above the ground) from the site in a single operation (Nisbet et al. 1997). In Ireland, in experimental trails conducted by Coillte, an adapted WTH procedure was adopted where the forest harvest residues are bundled and removed from the selected sites after the conventional harvesting of stem wood (personal communication, Dr. Philip O'Dea, Coillte Teoranta, 2010). To increase the understanding of the effect of whole-tree harvesting on P release, a small-scale pilot survey was also performed to investigate if the water extractable $\mathrm{P}$ (WEP) contents in soil below windrow/brash material are significantly higher than for areas without windrow/brash material.

Previous studies have indicated that vegetation can retain the available $\mathrm{P}$ in situ and reduce P release from forest activities. In Finland, Silvan et al. (2004) demonstrated that plants are effective in retaining $\mathrm{P}$ in peatlands. In China and Australia vetiver grass in buffer zones and wetlands has shown a huge potential for removing $\mathrm{P}$ from wastewater and polluted water (Wagner et al. 2003). Loach (1968) found that Molinia caerulea could uptake $3.4 \mathrm{~kg}$ $\mathrm{TP} / \mathrm{ha}$ in the wet-heath soils. Sheaffer et al. (2008) reported a P uptake of $30 \mathrm{~kg} / \mathrm{ha}$ by Phalaris arundinacea in their wastewater treatment sites. In this study we hypothesized that by stimulating the growth of the native grass species in the blanket peat forest area immediately after harvesting, significant amounts of $\mathrm{P}$ will be quickly taken up and conserved in situ, which will result in reduced P release sources. To test this hypothesis, a trial experiment was first carried out to identify the successful germination grass species in the blanket peatland. The grass species were then sown in three harvested blanket peat forest plots. The area without grass seeding worked as control. The biomass and P content of the above ground vegetation and the water extractable phosphorus in the study and control plots were tested one year after grass seeding.

\section{Study catchment description}

The Burrishoole catchment, located in County Mayo, Ireland, in the west of Ireland, consists of important salmonid productive rivers and lakes (Figure 1). About $18 \%$ of the catchment is covered by forests that were planted in the 1970s and which are now being, or are about to be, harvested. The study site $\left(9^{\circ} 55^{\prime} \mathrm{W} 35^{\circ} 55^{\prime} \mathrm{N}\right)$, which is a sub-catchment of the Burrishoole catchment drained by a small first order stream, was planted with Lodgepole Pine (Pinus contorta) between January and April 1971. The stream is equipped with two flow monitoring stations at stable channel sections, one upstream (US) and the other downstream (DS) of the experimental area. The US measures flows from the control area (area A in Figure 1) of 7.2 ha and the DS covers the control coupe and the experimental coupe (coupes B in Figure 1) with a total combined area of 17.7 ha. Before the start of this study, road 
drainage into the channel near the US gauge was diverted into an adjoining sub-catchment. In August 2005, a wind-blown tree blocked one of the collector drains, resulting in an increase of the upstream forest control area (coupe D), to about 10.8 ha (coupes A plus D in Figure 1). Meanwhile the downstream harvested area increased to about 14.5 ha due to the blockage of a drain by brash mat during the harvesting, incorporating another part of the total harvested area (coupe C). Fortunately, in both cases the additional area had the same characteristics of vegetation and soils, and the relative sizes of US and DS remained unchanged - US increasing only marginally from $41 \%$ of the total area to DS before harvesting and $43 \%$ afterwards. All unit area depths in this paper have been calculated using these values. The blanket upland peat soil in all four areas A - D had been double mouldboard ploughed by a Fiat tractor on tracks creating furrows and ribbons (overturned turf ridges) with a $2 \mathrm{~m}$ spacing, aligned down the main slope, together with several collector drains aligned close to the contour. The trees were planted on the ribbons at $1.5 \mathrm{~m}$ intervals, giving an approximate soil area of $3 \mathrm{~m}^{2}$ per tree. The initial stand density was about 2800 trees per ha but was reduced to about half by thinning and natural die-off before harvesting. The area was fertilized manually immediately after planting at a rate of $80 \mathrm{~kg}$ ground mineral phosphate (GMP) per ha - equivalent to $12 \mathrm{~kg} P$ per ha. This rate is low comparing with the normal rate of $250 \mathrm{~kg}$ GMP per ha. The catchment had an average peat depth of more than $2 \mathrm{~m}$ above the bedrock of quartzite, schist and volcanic rock, and the peat typically had a gravimetric water content of more than $80 \%$. In the catchments, the mean annual rainfall is more than $2000 \mathrm{~mm}$ and the mean air temperature is about $11{ }^{\circ} \mathrm{C}$. Hill slope gradients in areas $\mathrm{B}$ and $\mathrm{C}$ average $8^{\circ}$ and range between $0^{\circ}-16^{\circ}$. Bole-only harvesting was conducted in area B and C from July 25th to September 22nd 2005. The volume of lodgepole pine upon harvesting in area B (Figure 1) was about $400 \mathrm{~m}^{3} \mathrm{ha}^{-1}$. The timber was harvested using a Valmet 941 harvester, and the residues (i.e. needles, twigs and branches) were left on the soil surface and collected together to form windrows. During harvesting, the boles were stacked beside the windrow for collection. A Valmet 840 forwarder delivered the boles to truck collection points beside the forest service road. To minimise soil damage, the clearfelling and harvesting were conducted only in dry weather conditions during the period from July to September 2005. That time period is recommended for harvesting in the Irish Forest Harvesting and the Environment Guidelines since ground conditions tend to be drier (Forest Service, 2000b). Mechanised operations were suspended during and immediately after periods of particularly heavy rainfall. Another important good management practice used during the harvesting operation was the proper use of brash mats for machine travelling. Tree residues (i.e. needles, twigs and branches) were collected together to form brash mats on which the harvesting machines travelled, thus protecting the soil surface, and reducing erosion. The width of the windrows/brash mats is about $4 \mathrm{~m}$. The distance between two adjacent brash mats/windrows mats is about 12 $\mathrm{m}$. In the lowest part of the site where the stream is deeply incised, the trees were cut with a chain saw and left behind. The non-harvested upstream area of A and D, was used as a control area in this study as it had the same type and age of trees, similar soil, hydrologic characteristics and size, as the harvested experimental area of B and C. In the experimental area, the furrows and windrows/brash mats - formed from the harvest residues - are, in general, parallel with the study stream, which is at right angles to the contours. The surface water flows along the furrows, is collected by collector drains (arrows in Figure 1c) and joins the study stream. 
The second rotation of lodgepole pine was planted in December, 2005 at a density of 2,800 per ha with no cultivation and no new drainage. No fertilizer was applied in the replanting operation. A buffer zone was established by replanting birch, rowan, alder and willow (instead of pine), in a 15-20 m-wide strip on each side of the stream. Furrows, ribbons, drains and brash/windrows were left in situ. Very little re-vegetation was observed in the harvested area until late Summer, 2008.

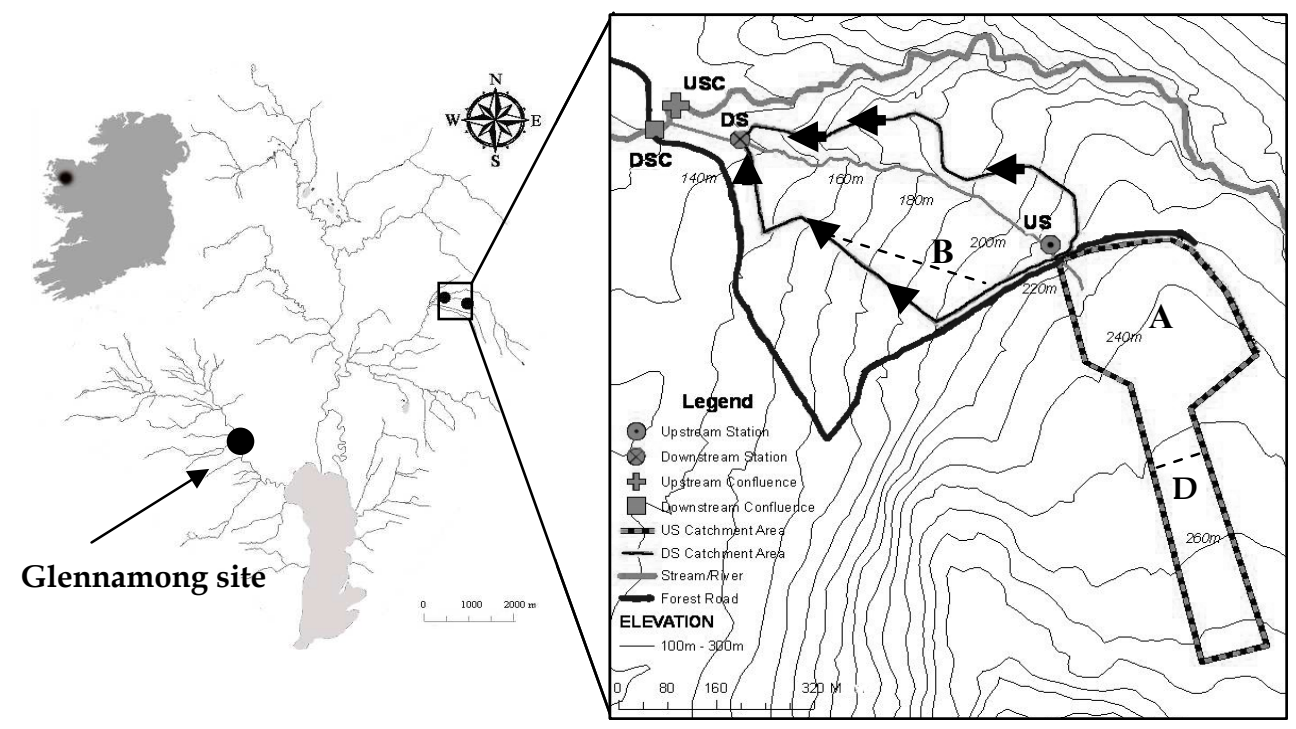

Fig. 1. Study sites

\section{Measurement and methods}

\section{1 sampling and measurement}

From April 2004 - March 2005, continuous water levels in the study stream were recorded at both the upstream station (US) and downstream station (DS), and converted to flows by a rating equation based on dilution gauging and current meter measurements. In April 2005, H-flume flow gauges were installed at the sites for flow measurement. At US and DS, water samples were taken: (i) manually every 20 minutes from April 2004 to March 2005 during flood events; (ii) hourly from April 2005 to September 2009 using ISCO automatic water samplers and (iii) manually in base flow conditions through the study period. Rainfall water samples were also collected by placing an open and clean plastic container near the DS station during storm events for P analysis. Suspended solid concentrations of the water samples were measured at the Marine Institute in Newport, Co. Mayo in accordance with the Standard Methods (APHA, 1995) using Whatman GF/C (pore size $1.2 \mu \mathrm{m}$ ) filter papers. Water samples collected May 2005 to September 2009 were analysed for phosphorus content. Water samples were frozen at $-20{ }^{\circ} \mathrm{C}$ in accordance with standard methods (APHA, 
1995) until water quality analyses were conducted. The following analyses were carried out on the water samples: total reactive phosphorus (TRP), dissolved reactive phosphorus (DRP) - filtered using Whatman Cellulose Nitrate Membrane Filters (pore size $0.45 \mu \mathrm{m}$ ) and total phosphorus (TP) - after digestion with acid persulfate - using a Konelab 20 Analyser (Konelab Ltd., Finland). Sites of about 1 ha in areas A and B were chosen for soil sampling. Forty and thirty-eight 100-mm-deep soil cores consisting of the humic and upper peat layers were collected using a 30-mm-diameter gouge auger from the ribbons in A and B in May 2005, April 2006, March 2007, April 2008 and March 2009. 15, 26, 25 and 28 more soil cores were taken under the windrow/brash in the DS harvested area in April 2006, March 2007, April 2008 and March 2009, respectively. Since the brash mats/windrows - formed from the harvest residues - are parallel to the study stream and furrows, and along the slope, P from the brash mats/windrows didn't enrich the brash-free soil. Soil samples were analyzed for gravimetric water content and water extractable $\mathrm{P}$ (WEP). The core samples were placed in bags, hand mixed until visually homogenized, and subsamples of approximately $0.5 \mathrm{~g}$ (dry weight) were removed and extracted in $30 \mathrm{ml}$ of distilled deionized water, and measured for P using a Konelab 20 Analyser. The remaining core samples were dried to determine their gravimetric moisture contents (Macrae et al., 2005).

In the Glennamong site, an area of about 1 ha was clearfelled in August 2009 and three plots of $100 \mathrm{~m}^{2}$ (plot 1), $360 \mathrm{~m}^{2}$ (plot 2) and $660 \mathrm{~m}^{2}$ (plot 3) were identified for the grass seeding plot-scale study. Each plot received the same sowing treatment, which comprised of a 50:50 ratio of Holcus lanatus and Agrostis capillaris. The ground was undisturbed and the seed was distributed evenly by hand at an initial rate of $36 \mathrm{~kg} \mathrm{ha}^{-1}$ on top of the old forest residue layer in October 2009. December 2009 and January 2010 were exceptionally cold months and a layer of snow measuring $30 \mathrm{~cm}$ in depth was recorded above the seeded area. To eliminate the risk of seed establishment failure the plots were seeded again in February 2010 at the same rate of $36 \mathrm{~kg}$ ha- 1 . The area which was not seeded was used as control. 100-mm-deep soil cores consisting of the humic and upper peat layers were collected using a $30-\mathrm{mm}$ diameter gouge auger in the Glennamong site one year after grass seeding. 4, 8 and 14 soil samples were taken from plot 1, 2 and 3, respectively. Soil samples were analyzed for gravimetric water content and water extractable P (WEP). To estimate the aboveground vegetation biomass in the study and control plots, thirty two $0.25 \mathrm{~m} \times 0.25 \mathrm{~m}$ quadrats were randomly sampled (Moore and Chapman 1986) in each site in August 2010. All vegetation lying within the quadrat was harvested to within $1 \mathrm{~cm}$ and dried at $80^{\circ} \mathrm{C}$ in the laboratory on the day of collection for 48 hours. Samples were then weighed and the biomass was calculated by using Equation 1. Total phosphorus (TP) content of the vegetation was measured in accordance with Ryan et al. (2001). About $1 \mathrm{~g}$ of dry matter from each sample was weighed, ground and put into a furnace at a temperature of $550 \mathrm{oC}$ overnight, then $5 \mathrm{ml}$ of $2 \mathrm{~N} \mathrm{HCl}$ was added to extract the $\mathrm{P}$ and subsequently diluted to $50 \mathrm{ml}$ with deionised water. P in the solution was analyzed using a Konelab 20 Analyser (Konelab Ltd.).

$$
B_{p}=\frac{W t}{S t} \times 10000
$$

Where $\mathrm{Bp}$ is the biomass production $(\mathrm{kg} / \mathrm{ha})$; Wt is the total dry weight of the samples $(\mathrm{kg})$ and $S t$ is the total area $(\mathrm{m} 2)$. 


\subsection{Analysis methods}

Storm flow was defined as the total flow (including the base flow) from the time where stream flow begins to increase on the rising limb to the time when the flow on the falling limb intercepts the separation line with a constant slope of $0.0055 \mathrm{~L} \mathrm{~s}^{-1} \mathrm{ha}^{-1}$ hour-1 (Yusop et al., 2006). Monthly TRP loading was calculated in base flow and storm flow periods as follows (Yusop et al., 2006):

$$
Q_{m T R P}=C Q_{m}
$$

where $\mathrm{Q}_{\mathrm{mTRP}}$ is monthly TRP load $\left(\mu \mathrm{g}\right.$ month $\left.^{-1}\right) ; \mathrm{C}$ is the discharge-weighted mean concentration $\left(\mu \mathrm{g} \mathrm{L}^{-1}\right)$ and $\mathrm{Q}_{\mathrm{m}}$ is the total flow $\left(\mathrm{L} \mathrm{month}^{-1}\right)$. For each month, $\mathrm{C}\left(\mu \mathrm{g} \mathrm{L}^{-1}\right)$ values at base flows and storm flows were calculated separately, using the following equation (Fergusson, 1987):

$$
C=\sum_{n=1}^{n} c_{i} q_{i} / \sum_{i=1}^{n} q_{i}
$$

where $c$ is the instantaneous concentration $(\mu \mathrm{g} \mathrm{L}-1)$, $\mathrm{q}$ the corresponding discharge during sampling $\left(\mathrm{L} \mathrm{s}^{-1}\right)$ and $\mathrm{n}$ is the number of low flow or storm flow samples in the respective month. Finally, the annual loading is calculated as the summation of monthly loadings during both low and storm flow periods.

The TRP loads were calculated using the following linear equation:

$$
Q_{T R P}=\alpha Q+\beta
$$

where QTRP represents the TRP yield $(\mu \mathrm{g}), \mathrm{Q}$ is the water discharge $(\mathrm{L})$, and $\alpha\left(\mu \mathrm{g} \mathrm{L}^{-1}\right)$ and $\beta$ $(\mu \mathrm{g})$ are obtained by the least squares method using observed TRP yield and water discharge data.

At the DS station, the values of $\alpha$ and $\beta$ in the base flow and storm flow were calculated for the following periods: August 2005 - July 2006, August 2006 - July 2007, August 2007 - July 2008, and August 2008 - July 2009. At the US station, because there was no significant change during the study period, the values of $\alpha$ and $\beta$ in the base flow and storm flow were calculated from August, 2005 to July, 2009.

The differences in WEP in soil in $\mathrm{kg} \mathrm{ha}^{-1}$ between the areas without windrow and with windrow were calculated by assuming that windrow comprises $25 \%$ of the harvested area and that soil density is similar in areas below windrow and without windrow.

The difference between the daily total reactive phosphorus (TRP) concentrations at the US and DS stations in the first four years after harvesting was analysed using a paired samples t-test at the $95 \%$ significance level $(\mathrm{P}=0.05)$. The difference between the soil WEP in A and B before harvesting was analysed using an independent samples t-test at the $95 \%$ significance level $(\mathrm{P}=0.05)$. After harvesting, the differences between the soil WEP in (i) area A and the brash/windrow-free area in B and (ii) under the brash/windrow and in the brash/windrowfree area in B were also analysed using an independent samples t-test at the $95 \%$ significance level $(\mathrm{P}=0.05)$. All the t-test was done with the SPSS statistical tool (http://www.spss.com). 


\section{Results and discussions}

\subsection{Suspended solids release}

During base flow conditions, suspended solid concentrations at the US and DS stations were generally low before and after harvesting and ranged from 0.1 to $5 \mathrm{mg} / 1$. Stream suspended solid are usually episodic - most solid is carried in high flows - so this study focused on the storm events. A rainfall event was defined as a block of rainfall that was preceded and followed by at least 12-hours of no rainfall (Hotta et al., 2007). A total of 23 events were studied in this paper: 8 before and 15 after harvesting. 114 and 394 water samples were collected at both stations before and after harvesting, respectively. Figure 2 shows the suspended solid concentrations and flows in some storm events before and after the harvesting period. As expected, variations in suspended solid concentration roughly correlate to the temporal profile of water discharge, and bigger storm events generally result in higher suspended solid concentrations. In most of the studied storms, suspended solid increased quickly at the beginning of the water discharge and reached the maximum prior to the water discharge peak, which could be due to the build-up of the soil fraction available for release and erosion prior to rainfall. Similar phenomena were also observed by Drewry et al. (2008) and Baca (2002).

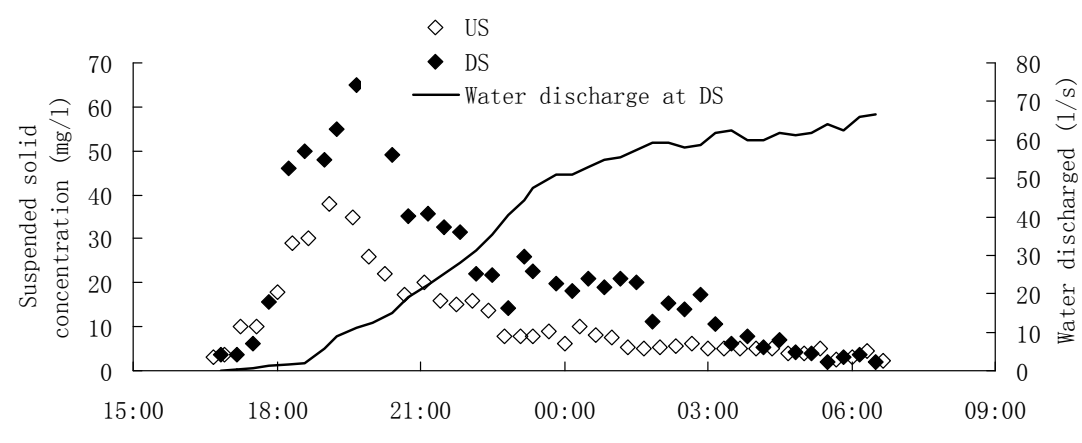

Time

Fig. 2. a. Pre-harvesting (22/06/2004)

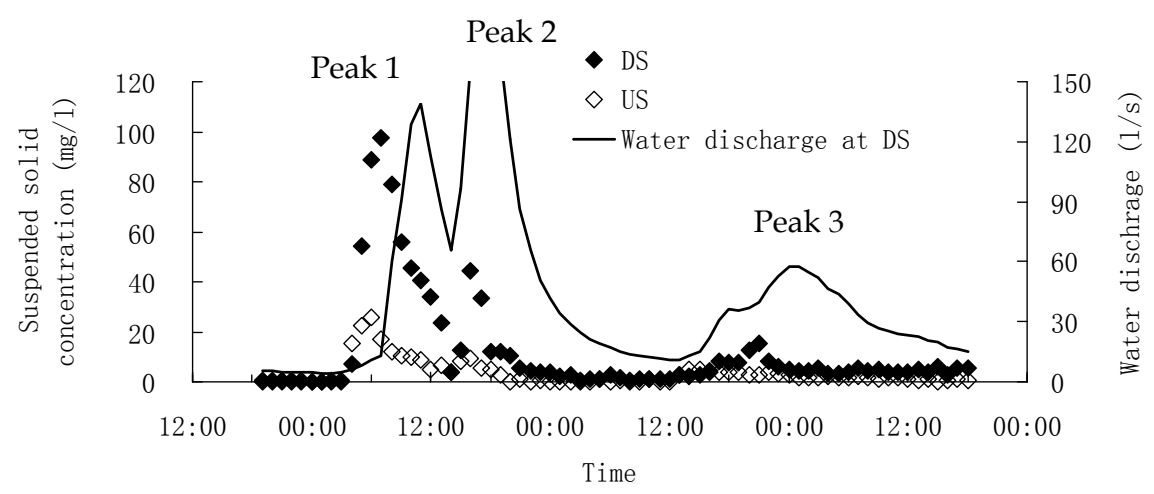

Fig. 2. b. Post-harvesting (1-4/11/2005) (The flume capacity was about 158 1/s) 
Figures $3 \mathrm{a}$ and $3 \mathrm{~b}$ show the relationships between suspended solid concentrations of the US and DS before and after harvesting, respectively. Larger scatter was found in the correlation of US and DS suspended solid concentrations after harvesting. In most of the storm events the peak flows passed US earlier than DS with the time difference of less than 30 minutes. Simple power equations were used to describe the solid relationships between the two stations:

$$
C_{D S}=a \cdot C_{U S}^{b}
$$

Where $\mathrm{C}_{\mathrm{DS}}$ and $\mathrm{C}_{\mathrm{US}}$ are the suspended solid concentrations at DS and US stations, and a and $\mathrm{b}$ were obtained by the least squares method.

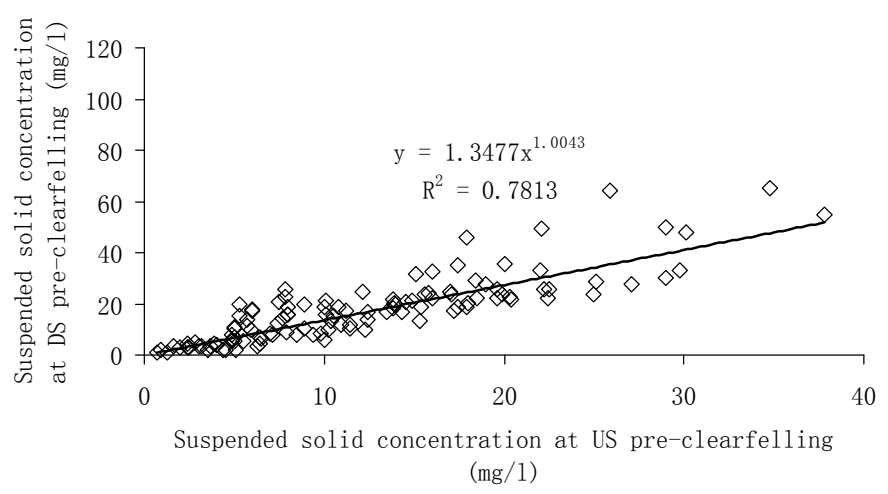

Fig. 3. a.

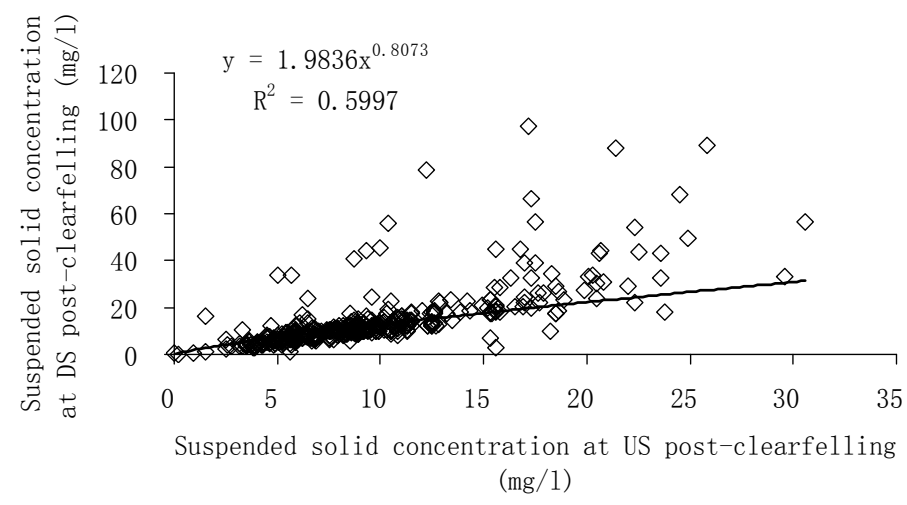

Fig. 3. b.

Fig. 3. The relationship between the suspended solid concentrations at US and DS stations (Figure $3 \mathrm{a}$ before harvesting; $3 \mathrm{~b}$ after harvesting) 
Parameter a increased from about 1.35 before harvesting to about 1.98 after harvesting and $\mathrm{b}$ decreased from 1.01 to 0.81 . In order to examine the impact of the harvesting activities on the sediment release, the solid at DS was estimated as the dependent variable by using the pre-harvesting power function equation $(a=1.35$ and $b=1.0)$ and the observed postharvesting solid at US as the independent variable. The estimated and measured solid concentrations at DS were compared using a paired samples t-test at the $95 \%$ significance level $(\mathrm{P}=0.05)$ (http://www.spss.com), which indicated that there was no statistically significant difference between the estimated and measured concentrations.

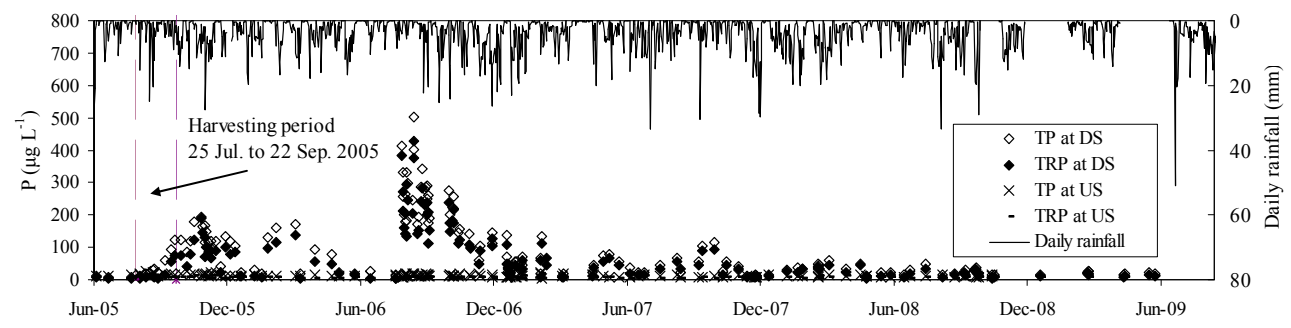

Fig. 4. The daily rainfall and daily discharge-weighted mean total phosphorus (TP) and total reactive phosphorus (TRP) concentrations at downstream station (DS) and upstream station (US) during the study period

\subsection{Phosphorus release}

\subsubsection{General trends}

The average P concentrations in the rainfall were $13 \pm 6 \mu \mathrm{g} \mathrm{L}^{-1}$ of TP and $4 \pm 3 \mu \mathrm{g} \mathrm{L}^{-1}$ of TRP. Figure 4 shows the daily discharge-weighted mean TP and TRP concentrations at US and DS stations during the study period. The release pattern of $\mathrm{P}$ concentrations - increasing to a clear peak after harvesting, experiencing a distinct declining tail, and then increasing to the maximum peak in the next summer - was also observed by Cummins and Farrell (2003) in a study carried out in a blanket peatland forest in the west of Ireland. The maximum peak in the next summer after harvesting was also observed by Nieminen (2003) in a Scots pinedominated peatland in southern Finland. The daily discharge-weighted mean $P$ concentrations at the DS station reduced to less than $15 \mu \mathrm{g} \mathrm{L}-1$ of TRP and $20 \mu \mathrm{g} \mathrm{L}-1 \mathrm{of}$ TP in July 2009, four years after harvesting. Statistical analysis indicated that $\mathrm{P}$ concentrations at the DS station were significantly higher than that at the US station $(\mathrm{P}=0.05)$ in the 4-year period following harvesting. Figure 5 shows the relationship between the DRP, TRP and TP at the DS station during the study period. Linear regressions were established for DRP and TRP versus TP. TRP and DRP were about $87 \%$ and $77 \%$ of TP, respectively, which indicated that: (1) the majority of TP was reactive and (2) particulate $\mathrm{P}$ concentrations were low. Renou-Wilson and Farrell (2007) found that in water samples with high organic matter content, TRP may be equal to TP.

\subsubsection{Effect of storm flow events}

Over 120 storm events were analysed in this study. Along with being influenced by the elapsed time after harvesting, P concentrations were also affected by the flow rates (Figure 6). 


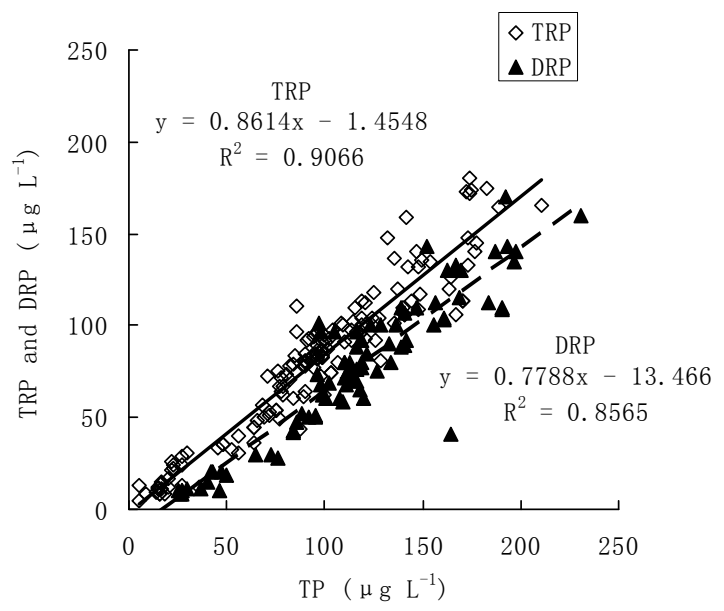

Fig. 5. The relationship between the instantaneous concentrations of dissolved reactive phosphorus (DRP), total reactive phosphorus (TRP) and their linked total phosphorus (TP) concentration at downstream station (DS) during the study period

In over $80 \%$ of the monitored storm events, $\mathrm{P}$ concentrations increased at the discharge rising stage, reached the maximum prior to the peak flow rate, and then reduced to a relatively stable value. The major part of the $\mathrm{P}$ loading in receiving waters after harvesting activities was derived from the $\mathrm{P}$ movement from the topsoil to the stream during overland flow events (McDowell and Wilcock, 2004; Monaghan et al., 2007). Shigaki et al. (2006) and Quinton et al. (2001) found that high rainfall intensity resulted in a greater degree and depth of interaction between runoff and surface soil, including high runoff DRP concentrations, compared to what occurs during low rainfall intensities. The P concentrations were also affected by antecedent weather conditions. In the storm event of November 2nd 2005, peak TRP concentrations were $197 \mu \mathrm{g} \mathrm{L}^{-1}, 106 \mu \mathrm{g} \mathrm{L}^{-1}$ and $113 \mu \mathrm{g} \mathrm{L}^{-1}$ in Events 1, 2 and 3 (Figure 6). The peak TRP concentration in Event 2 was lower than in Event 1, although the flow rate was higher, which could be due to less labile P sources being available for release in Event 2 . When a storm event follows immediately after a previous storm event, much of the labile $\mathrm{P}$ has already been removed by the previous flood (Bowes et al., 2005). Similar phenomena were also observed in other storm events.

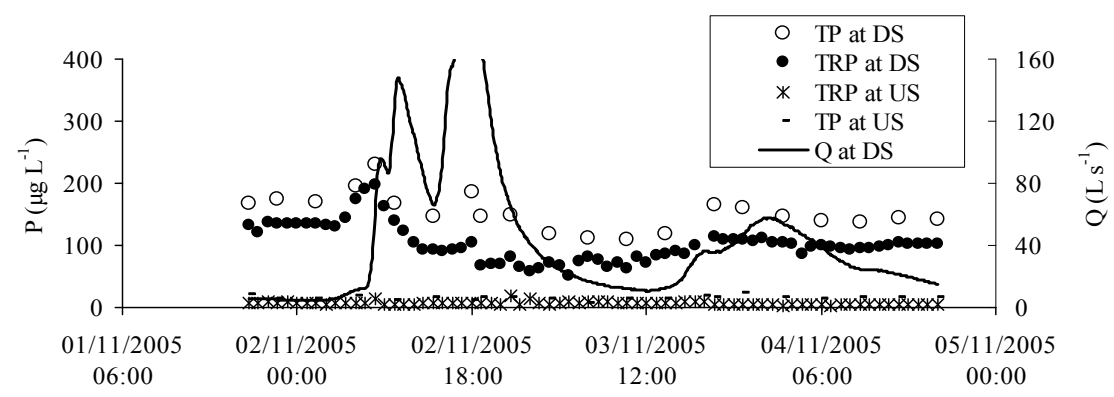

Fig. 6. The instantaneous $P$ concentrations at upstream station (US) and downstream station (DS) with the instantaneous DS flow rate (Q) in a storm event 


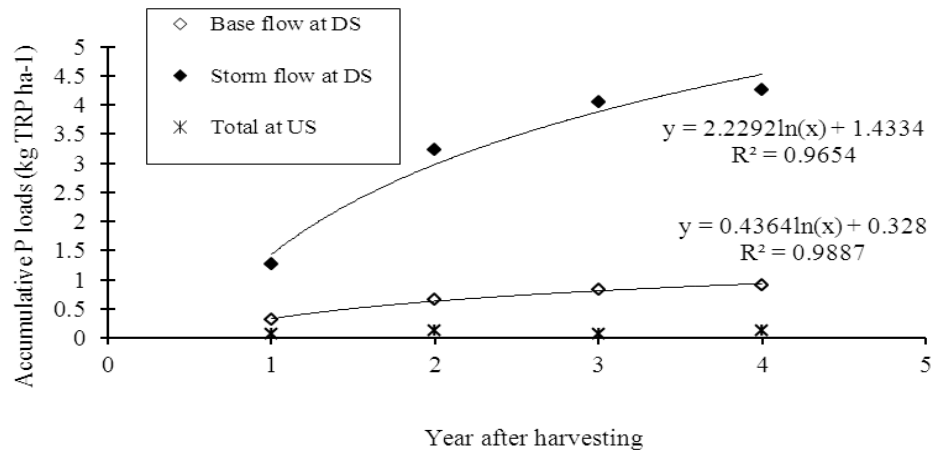

Fig. 7. Accumulative total reactive phosphorus (TRP) loads from the control site (US) and from the harvested area (DS) in base flow and storm flow after harvesting

\subsubsection{Phosphorus loads}

Annual TRP loads from the control area were steady and low during the study period, with values of less than $60 \mathrm{~g} \mathrm{ha}^{-1}$. Figures 7 shows the TRP loads from the harvested area in base flow and storm flow in the first 4 years after harvesting. A total of about $5.15 \mathrm{~kg}$ ha- 1 of TRP was released from the harvested area in the four years after harvesting, and mainly occurred in the first three years. The highest TRP load of $2303 \mathrm{~g} \mathrm{ha}^{-1}$ was recorded in the second year after harvesting. Most of the TRP was released in storm events.

\subsection{4 $\mathrm{P}$ concentrations in downstream river}

Phased felling is recommended in the UK (Forest Commission 1988) and Ireland (Forest Service 2000a) to diminish the negative impact of harvesting on water quality. Harvesting appropriately sized coupes in a catchment at any one time can minimise the nutrient concentrations in the main rivers (Rodgers et al. 2010). In their study, Cummins and Farrell (2003) found that the study streams had P concentrations well above critical levels for eutrophication, but they didn't know what implications these pollutions had for downstream river-water quality in larger channels. This study found that the $P$ concentration at the DS station in the study stream did not have a large impact on the $\mathrm{P}$ concentration in the main river, which covers an area of 200 ha above its confluence with the study stream and should have a dilution factor of about 8 for the study stream. These preliminary results indicated that catchment-based selection of the harvesting coupe size could limit the $\mathrm{P}$ concentrations in the receiving waters after harvesting.

\subsubsection{Water extractable $P$ concentrations of the soil after harvesting}

Figure 8 shows the WEP of the soil between the windrows and areas under the windrows in the DS harvested area and the US control area in May 2005, April 2006, March 2007, April 2008 and March 2009. The independent samples t-test indicated that (i) before harvesting (in May, 2005), the difference between the WEP concentrations in area A and area B was not significant; (ii) after harvesting (in April, 2006 and March, 2007), WEP concentrations were significantly higher in the brash/windrow-free soils in area B than in area A ( $P=0.05)$; (iii) in 
the harvested area $\mathrm{B}$, the WEP concentrations under the windrows/brash were significantly higher than those in the windrow/brash-free area in April 2006, March 2007, April 2008 and March 2009 ( $\mathrm{P}=0.05)$. The high WEP value under the windrows/brash material lasted longer than for the windrow-free areas, which could be due to the relatively low decomposition rates of bark and branches (Ganjegunte et al., 2004).

\subsection{Possible mitigation methods}

\subsubsection{Whole tree harvesting, buffer zone and phased felling}

In order to reduce nutrient sources after harvesting, whole-tree harvesting is recommended (Nisbet et al., 1997). Needles and branches have much higher nutrient concentrations than stem wood. Whole-tree harvesting may reduce nutrient sources by 2 to 3 times more than bole-only harvesting (Nisbet et al., 1997). This study found higher WEP contents in harvested areas below windrow/brash material than for the brash-free sites, indicating that whole-tree harvesting could be used as a means to decrease P release.

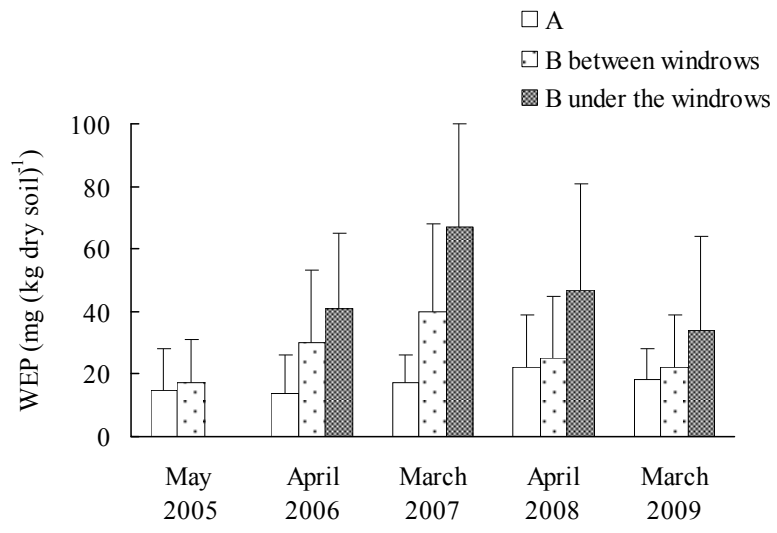

Fig. 8. Soil water extractable phosphorus (WEP) in non-harvested (A) and harvested areas (B) between the windrow and under the windrow in May 2005, April 2006, March 2007, April 2008 and March 2009 (The bars indicate the standard deviation)

A buffer zone is an area adjacent to an aquatic zone and managed for the protection of water quality (Forest Service, 2000a). Within buffer zones, natural vegetation and/or planted suitable tree species are allowed to develop. Buffer zone has been widely used by forestry practitioners in the protection of freshwater aquatic systems (Newbold et al., 2010). However, this study shows that traditional buffer zones may not be an efficient method to mitigate the $\mathrm{P}$ release from all harvested areas, since, in this study, about $80 \%$ of TP in the study stream was soluble and more than $70 \%$ of the $\mathrm{P}$ release occurred in storm events when there would have been low residence times for the uptake of soluble $\mathrm{P}$ in the buffer zones. In fact, using buffer zones to reduce $P$ release could do the opposite, as the buffer zones which usually adjoin to the water body could become P release sources (Uusi-Kämppä, 2005).

Phased felling and limiting size to minimise negative effects have been recommended in the UK (Forestry Commission, 1988) and Ireland (Forest Service, 2000a). Harvesting proper 
proportion of a catchment at any one time can reduce the nutrient concentrations on aquatic systems. This study found that due to the dilution capacity of the main river, the $\mathrm{P}$ concentrations in the river were low after harvesting, indicating that catchment-based selection of the harvesting coupe size could limit the $\mathrm{P}$ concentrations in the receiving waters after harvesting. However, the management strategy does not reduce the total $\mathrm{P}$ load leaving the harvested catchment.

\subsubsection{A possible novel practice - Grass seeding}

Figures 9 shows the P content of the above ground biomass in the sown and control plots. Seeding of Holcus lanatus and Agrostis capillaris increased the above ground vegetation $\mathrm{P}$ content one year after grass seeding. While there was very little vegetation growth in the control plots (22 kg biomass ha- 1 with P content of $0.02 \mathrm{~kg}$ TP ha- 1 ), vegetation biomass of $2753 \mathrm{~kg}$ ha- $1,723 \mathrm{~kg}$ ha-1 and $2050 \mathrm{~kg}$ ha- 1 were observed in the three study plots, giving the TP content of $2.83 \mathrm{~kg}$ ha- $1,0.65 \mathrm{~kg}$ ha- 1 and $3.07 \mathrm{~kg}$ ha-1, respectively (Figure 9). The P content of above ground biomass in the sown plots was significantly higher than in the control plots ( $\mathrm{t}$ test, $\mathrm{p}<0.01$ ). The vegetation collected for testing was cut to $1 \mathrm{~cm}$ aboveground level so these estimates could in fact be higher when taken below ground biomass production into account which has been estimated at $30 \%$ of the total plant biomass (Scholes and Hall 1996). In the UK, Goodwin et al. (1998) found that Holcus lanatus produced biomass of $3405 \mathrm{~kg}$ ha- 1 with P concentrations of $1.64 \mathrm{mg}$ TP (g biomass)-1, giving the total P content of $5.58 \mathrm{~kg} \mathrm{P}$ ha-1. Figure 10 shows the water extractable phosphorus (WEP) concentrations in the sown plots and the control plots. The WEP in the three study plots were $9 \mathrm{mg} \mathrm{P}$ (kg dry soil)-1, $12 \mathrm{mg} \mathrm{P} \mathrm{(kg} \mathrm{dry} \mathrm{soil)-1} \mathrm{and} 6 \mathrm{mg} \mathrm{P} \mathrm{(kg} \mathrm{dry} \mathrm{soil)-1,} \mathrm{respectively,}$ which was significantly lower than the value of $27 \mathrm{mg} \mathrm{P}$ ( $\mathrm{kg}$ dry soil)-1 in the control areas (Figure 9) (t-test, p < 0.01).

Future research on the potential of grass seeding as forestry BMP should measure stream chemistry to assess the success of the practice at protection water quality. It is expected that the $\mathrm{P}$ measured in the grass would render a corresponding reduction in the $\mathrm{P}$ exported by the stream after harvesting. However this has not been addressed by this study. Sowing grass immediately after harvesting may affect forest regeneration.
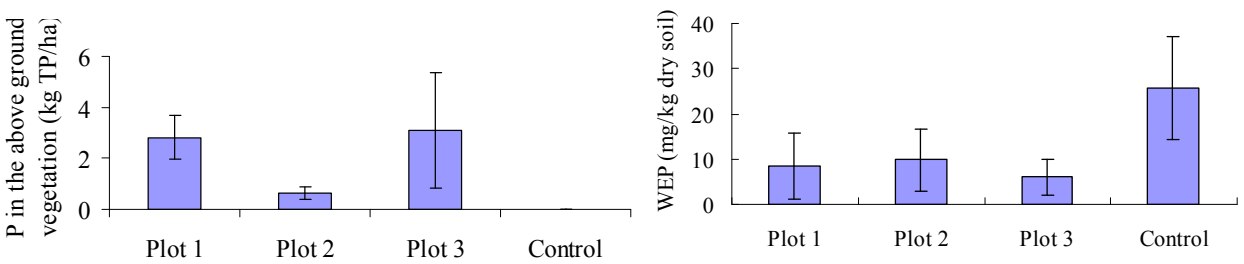

Fig. 9. P content of above ground vegetation and soil WEP in the study plots and control in the Glennamong

\section{Conclusions}

The results of this study indicated that post-guideline harvesting (1) did not have long-term impact on the suspended solid concentrations and did not change the erosion characteristics 
of the catchment, but (2) increased the TRP export in the study stream, and this impact could last for more than four years. In the first three years following harvesting, up to 5.15 $\mathrm{kg}$ ha- 1 of TRP were released from the catchment to the receiving water; in the second year alone after harvesting, $2.3 \mathrm{~kg}$ ha- 1 were released.

About $80 \%$ of TP in the study stream was soluble and more than $70 \%$ of the P release occurred in storm events, indicating that traditional buffer zones may not be an efficient method to mitigate the P release from all harvested areas. Due to the dilution capacity of the main river, the $\mathrm{P}$ concentrations in the river were low during the study period, indicating that rational sizing of the harvesting coupe could be an efficient practice to limit the $\mathrm{P}$ concentration in the receiving waters following harvesting. However, the study comprised only one experimental catchment. In future research, more paired sites should be investigated. Higher WEP concentrations found under the windrows/brash material, were due to $\mathrm{P}$ release from decomposing logging residues. This indicates that whole-tree harvesting could, at least to some extent, be used as a means to decrease P release from blanket peats. The results of this study also indicate that Holcus lanatus and Agrostis capillaris can be quickly established in blanket peat forest areas after harvesting and has the potential to immobilize the $\mathrm{P}$ that would otherwise be available for leaching. Further research into the feasibility of grass seeding as a potential new best management practice is clearly warranted.

\section{References}

APHA. (1995). Standard Methods for Examination of Water and Wastewater, 19th edition. American Public Health Association, Washington.

Baca, P. (2002). Temporal variability of suspended sediment availability during rainfallrunoff events in a small agricultural basin. ERB and Northern European FRIEND Project 5 Conference, Demänovská dolina, Slovakia.

Bowes M.J., House A.W., Hodgkinson A.R and Leach V.D. (2005). Phosphorus - discharge hysteresis during storm events along a river catchment: the River Swale, UK. Water Res. 39, 751-762.

Coillte Teo. (2007). Code of Best practice for the management of water run off during forest operations. Coillte, Newtownmountkennedy, Co. Wicklow, Ireland

Cummins, T., and E. P. Farrell. (2003). Biogeochemical impacts of clearfelling and reforestation on blanket peatland streams I. phosphorus. Forest Ecology and Management, 180(1-3), 545-555.

Drewry, J. J., Cameron, K. C. and Buchan, G. D. (2008). Pasture yields and soil physical property responses to soil compaction from treading and grazing: a review. Australian Journal of Soil Research 46: 237-256

EEA. (2004). Revision of the assessment of forest creation and afforestation in Ireland. Forest Network Newsletter Issue 150, European Environmental Agency's Spatial Analysis Group

Farrell, E.P. (1990). Peatland forestry in the Republic of Ireland. In: Biomass Production and Element Fluxes in Forested Peatland Ecosystems, Hånell, B., Ed., Umea, Sweden, 13, 1990.

Fergusson, R.I. (1987). Accuracy and precision of methods for estimating river loads. Earth Surf. Proc. Land 12, 95-104. 
Forestry Commission. (1988). Forests and water guidelines. 1st ed. London: HMSO. Revised (2nd ed. 1991, 3rd ed. 1993, 4th ed. 2003)

Forest Service. (2000a). Forest Harvesting and the Environment Guidelines. Irish National Forest Standard. Forest Service, Department of the Marine and Natural Resources, Dublin.

Forest Service. (2000b). Forestry and Water Quality Guidelines. Forest Service Guideline. Forest Service, Department of the Marine and Natural Resources, Dublin.

Forest Service. (2000c). Code of Best Forest Practice - Ireland. Irish National Forest Standard. Forest Service, Department of the Marine and Natural Resources, Dublin.

Forest Service. (2000d). Forest Harvesting and the Environment Guidelines. Irish National Forest Standard. Forest Service, Department of the Marine and Natural Resources, Dublin.

Ganjegunte K.G., Condron M.L, Clinton W.P., Davis R.M. and Mahieu N. (2004). Decomposition and nutrient release from radiate (Pinus radiata) coarse woody debris. Forest Ecol. Manag. 187: 197-211.

Goodwin, M. J., R. J. Parkinson, E. N. D. Williams, and J. R. B. Tallowin. (1998). Soil phosphorus extractability and uptake in a Cirsio-Molinietum fen-meadow and an adjacent Holcus lanatus pasture on the culm measures, north Devon, UK. Agriculture, Ecosystems \& Environment, 70(2-3), 169-179.

Hotta N., Kayama T. and Suzuki M (2007). Analysis of suspended sediment yields after low impact forest harvesting. Hydrological processes 21: 3565-3575

Loach, K. (1968). Seasonal Growth and Nutrient Uptake in a Molinietum. Journal of Ecology, 56(2), 433-444.

Macrae M.L., Redding T.E., Creed I.F., Bell W.R. and Devito K. J. (2005). Soil, surface water and ground water phosphorus relationships in a partially harvested Boreal Plain aspen catchment. Forest Ecol. Manag. 206, 315-329.

McDowell, R.W., Wilcock, R.J. (2004). Particulate phosphorus transport within stream flow of an agricultural catchment. J. Environ. Qual. 33, 2111-2121.

Monaghan R.M., Wilcock R.J., Smith L.C., Tikkisetty B., Thorrold B. S., and Costall D. (2007). Linkages between land management activities and water quality in an intensively farmed catchment in southern New Zealand. Agr Ecosyst Environ 118, 211-222.

Moore, P. D. and S.B. Chapman. (1986). Methods in Plant Ecology, Alden Press, Oxford.

Newbold D. J., Herbert S., Sweeney W. B., Kiry P. and Alberts J.S. (2010). Water quality functions of a 15-year-old riparian forest buffer system. J Am Water Resour As. 46(2):299-310

Nieminen, M. (2003). Effects of clear-cutting and site preparation on water quality from a drained Scots pine mire in southern Finland. Boreal Env. Res. 8: 53-59.

Nisbet T, J. Dutch and A.J. Moffat (1997). Whole-tree harvesting: a guide to good practice. Forestry practice guide, London, HMSO.

Nisbet T.R. (2001). The role of forest management in controlling diffuse pollution in UK forestry. Forest Ecol. Manag. 143, 215-226.

Quinton J.N., Catt J.A., Hess T.M. (2001). The selective removal of phosphorus from soil: is event size important? J Environ Qual 30, 538-545

Renou-Wilson. F. and Farrell P. E., 2007. Phosphorus in surface runoff and soil water following fertilization of afforested cutaway peatlands. Boreal Env. Res 12, 693-709. 
Rodgers, M., M. O'Connor, M. G. Healy, C. O’Driscoll, Z. Asam, M. Nieminen, R. Poole, M. Muller, and L. Xiao. (2010). Phosphorus release from forest harvesting on an upland blanket peat catchment. Forest Ecology and management , doi:10.1016/j.foreco.2010.09.037

Ryan J., E. George, and R. Abdul. (2001). Soil and plant analysis laboratory manual. Second edition. Jointly published by the International Certer for Agricultural Research in the Dry Areas and the National Agricultural Research Center. Available from ICARDA, Aleppo, Syria.

Ryder, L., E. de Eyto, M. Gormally, M. Sheehy-Skeffington, M. Dillane and R. Poole. (2010). Riparian zone creation in established coniferous forests in Irish upland peat catchments: Physical, Chemical and Biological Implications. Biology and Environment: Royal Irish Academy. (In press).

Scholes, R.J. and D. O. Hall. (1996). The carbon budget of tropical savannas, woodlands and grasslands. In: Breymeyer A.I., D. O. Hall, J. M. Melillo, and G. I. Agren. (Eds.) Global Change: Effects on Coniferous Forests and Grasslands, SCOPE Volume 56. Wiley, Chichester.

Sheaffer C.C., Rosen C.J. and Gupta S.C. (2008). Reed Canarygrass Forage Yield and Nutrient Uptake on a Year-round Wastewater Application Site. Journal of Agronomy and Crop Science, 194 (6), 465-469

Shigaki F., Sharpley A.N. and Prochnow I. L., 2006. Rainfall intensity and phosphorus source effects on phosphorus transport in surface runoff from soil trays. Sci Total Environ, doi:10.1016/j.scitotenv.2006.10.048

Silvan N., H. Vasander, and J Laine. (2004). Vegetation is the main factor in nutrient retention in a constructed wetland buffer. Plant soil, 25, 179-187

Stott T., Leeks G., Marks S. and Sawyer A. 2001. Environmentally sensitive plot-scale timber harvesting: impacts on suspended sediment, bedload and bank erosion dynamics. Journal of Environmental Management 63: 3-25.

Uusi-Kämppä, J. (2005). Phosphorus purification in buffer zones in cold climates. Ecological Engineering, 24(5), 491-502.

Wagner, S., P. Truong, A. Vieritz, and C. Smeal. (2003). Response of Vetiver Grass to Extreme Nitrogen and Phosphorus Supply. In: Proceedings of Third International Vetiver Conference, Guangzhou, China. October 2003.

Yusop Z., Douglas I., Nik R.A. (2006). Export of dissolved and undissolved nutrients from forested catchments in Peninsular Malaysia. Forest Ecol. Manag. 224, 26-44. 


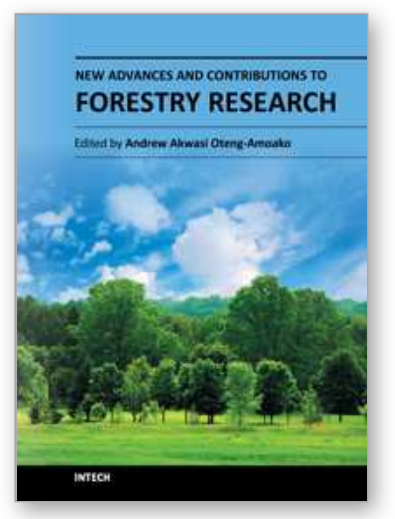

\section{New Advances and Contributions to Forestry Research}

Edited by Dr. Dr. Andrew A. Oteng-Amoako

ISBN 978-953-51-0529-9

Hard cover, 256 pages

Publisher InTech

Published online 27, April, 2012

Published in print edition April, 2012

New Advances and Contributions to Forestry Research consists of 14 chapters divided into three sections and is authored by 48 researchers from 16 countries and all five continents. Section Whither the Use of Forest Resources, authored by 16 researchers, describes negative and positive practices in forestry. Forest is a complex habitat for man, animals, insects and micro-organisms and their activities may impact positively or negatively on the forest. This complex relationship is explained in the section Forest and Organisms Interactions, consisting of contributions made by six researchers. Development of tree plantations has been man's response to forest degradation and deforestation caused by human, animals and natural disasters. Plantations of beech, spruce, Eucalyptus and other species are described in the last section, Amelioration of Dwindling Forest Resources Through Plantation Development, a section consisting of five papers authored by 20 researchers. New Advances and Contributions to Forestry Research will appeal to forest scientists, researchers and allied professionals. It will be of interest to those who care about forest and who subscribe to the adage that the last tree dies with the last man on our planet. I recommend it to you; enjoy reading it, save the forest and save life!

\section{How to reference}

In order to correctly reference this scholarly work, feel free to copy and paste the following:

Liwen Xiao, Michael Rodgers, Mark O'Connor Connie O'Driscoll and Zaki-ul-zaman Asam (2012). Assessment and Mitigation of Nutrients Losses from Forest Harvesting on Upland Blanket Peat - A Case Study in the Burrishoole Catchment, New Advances and Contributions to Forestry Research, Dr. Dr. Andrew A. OtengAmoako (Ed.), ISBN: 978-953-51-0529-9, InTech, Available from: http://www.intechopen.com/books/newadvances-and-contributions-to-forestry-research/assessment-and-mitigation-of-nutrients-losses-from-forestharvestingg-on-upland-blanket-peat-

\section{INTECH}

open science | open minds

\author{
InTech Europe \\ University Campus STeP Ri \\ Slavka Krautzeka 83/A \\ 51000 Rijeka, Croatia \\ Phone: +385 (51) 770447 \\ Fax: +385 (51) 686166
}

\author{
InTech China \\ Unit 405, Office Block, Hotel Equatorial Shanghai \\ No.65, Yan An Road (West), Shanghai, 200040, China \\ 中国上海市延安西路65号上海国际贵都大饭店办公楼 405 单元 \\ Phone: +86-21-62489820 \\ Fax: +86-21-62489821
}


www.intechopen.com 
(C) 2012 The Author(s). Licensee IntechOpen. This is an open access article distributed under the terms of the Creative Commons Attribution 3.0 License, which permits unrestricted use, distribution, and reproduction in any medium, provided the original work is properly cited. 